\title{
THE FLOODABLE PARK “LA MARJAL” (ALICANTE, SOUTH EAST SPAIN) AS A PARADIGMATIC EXAMPLE OF WATER REUSE AND CIRCULAR ECONOMY
}

\author{
ANTONIO JODAR-ABELLAN, JOAQUIN MELGAREJO \& MARIA INMACULADA LOPEZ-ORTIZ \\ University Institute of Water and Environmental Sciences, University of Alicante, Spain
}

\begin{abstract}
Nowadays, the south-east of Spain has several problems of water supply due to high agricultural, urban, industries, and so one water demands. In addition, this sensible area has limited precipitations, high temperatures and evapotranspiration rates. At the same time, in many places, the urban growth has been poorly organized. Usually, some areas are subjected to the effects of flash floods caused by heavy and concentrated rainfalls. In this work, we analyse the evolution of the floodable park "La Marjal" (Alicante, SE Spain) since its construction two years ago as a solution to reduce the mentioned problems. This floodable park, the first constructed in Spain and the second in Europe, cost 3.3 M€ and presents a total water volume of $45,000 \mathrm{~m}^{3}$. The park gets to avoid typical flash floods in San Juan urban area and provides storage of water to reuse it in irrigation of urban parks and gardens, countries, street cleaning, and other uses.
\end{abstract}

Keywords: circular economy, water reuse, flash floods, floodable park "La Marjal".

\section{INTRODUCTION}

Circular economy is a new economic trend related principally with a sustainable development. The main objective of this concept consist on preserve the value of products, materials and resources (water, energy and so one) the most time as possible into the economy. At the same time, it pretends to obtain a high reduction of the generated waste products into the economic cycle. The aim is to implement a new circular, non-linear, economy based on the principle of "closing the life cycle" of products, services, waste products, materials, water and energy. In summary, principal benefits of circular economy can be listed as follow: 1-Reduce water consumption and energy in industrial processes. Therefore, some authors consider circular economy as a valid instrument to avoid climate change; 2-Decrease waste generation getting it conversion into raw materials; 3-Preserve raw materials; 4-Generate new uses of products; 5-Create wealth and employment (local employment and hard to relocate); 6-Drive innovation (McKinsey and Company [1]) Melgarejo and Prats-Rico [2]). Fig. 1 shows a generic system diagram that represents the constant flow of biological and technical materials through the "value circle".

\subsection{Water reuse into circular economy}

In the water sector, the circular economy concept is based on reusing water the maximum as possible simulating a natural hydrological cycle. In the urban sector, using regenerated wastewater, circular economy pretends to mitigate net consumption of water, reusing it in different applications (agricultural irrigation, parks and gardens, cleaning...). In the industrial sector, the regenerated water coming from effluents can be reused to generate new products, use process and cooling water among other applications. Therefore, it can be reduced environmental impacts derived from industrial activities and save costs. In this way, it is perfectly possible to extract and recover valuable resources contained in different industrial 
and municipal effluents (McKinsey and Company [1]; Melgarejo and López-Ortiz [4]). Fig. 2 represents a generic reuse of wastewater into circular economy.

Consequently, circular economy of water is a valid mechanism to avoid problems derived from droughts and water scarcity. It allows to access water resources in areas with water restrictions and to prevent futures scenarios due to it is expected that water consumption will double by 2050 over the world (McKinsey and Company [1]; Melgarejo and Prats-Rico [2]). In south eastern Spain, Segura River basin and also Júcar and Sur basins present high levels of water scarcity, in particular in the provinces of Murcia, Alicante and Almeria. These areas also suffer high rainfall events (storms) generating flash floods problems (CamarasaBelmonte [5]; Valdés-Abellán et al. [6]; Melgarejo and López-Ortiz [4]).

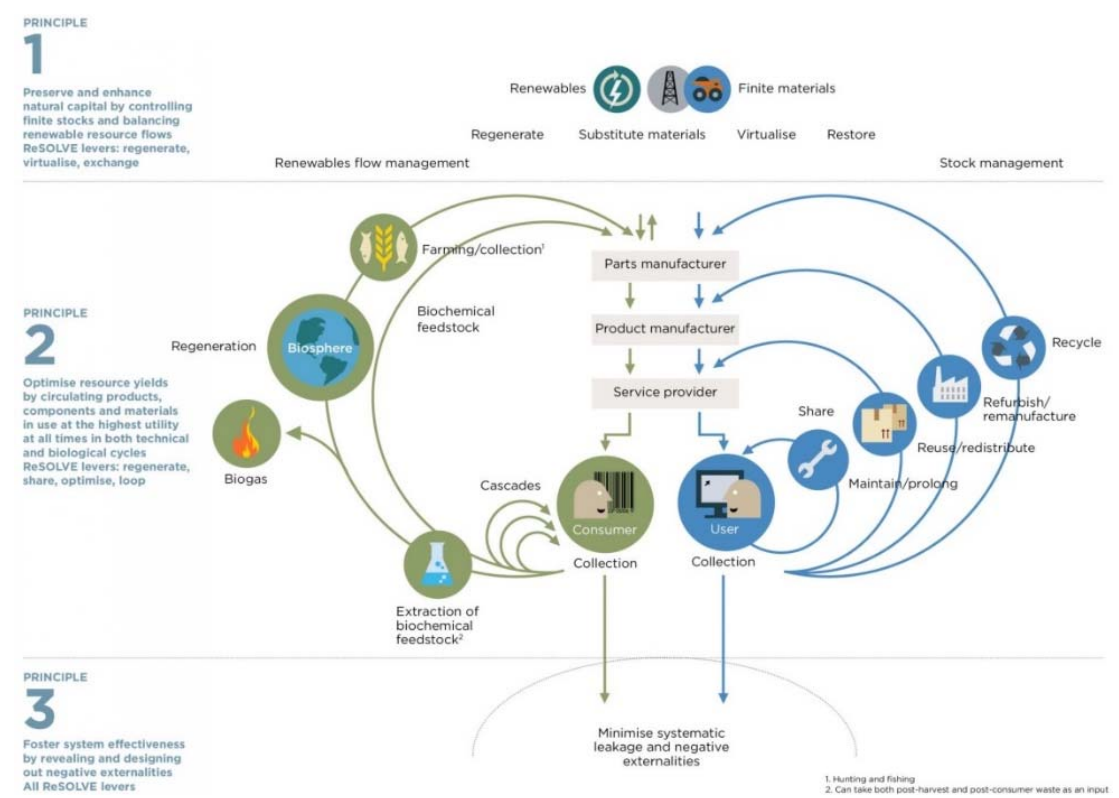

Figure 1: Diagram of a circular economy system. (Source: Adapted from [3].)

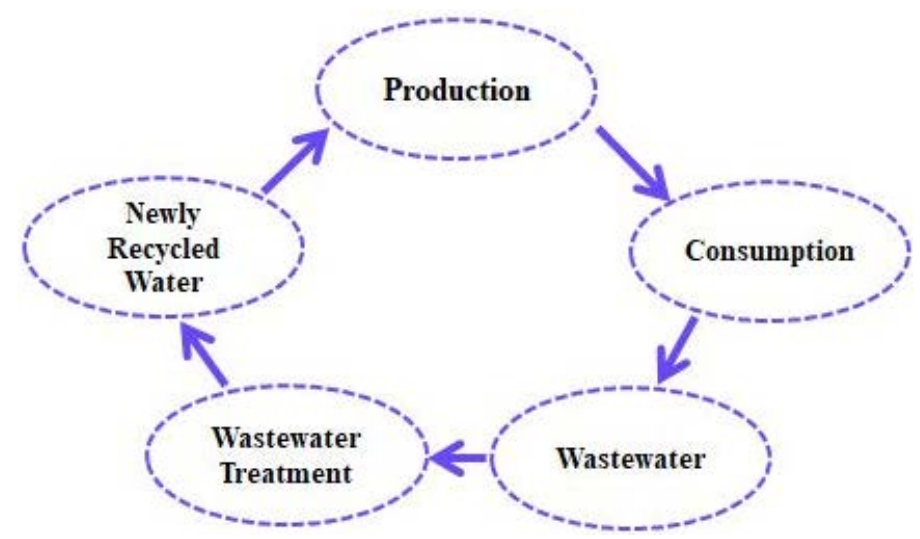

Figure 2: Wastewater reuse into a circular economy diagram. 


\subsection{Objective}

In the present work, we study the floodable park "La Marjal" (Alicante, SE Spain) as an important element to prevent the above issues and to produce storage of water to reuse it into circular economy of water.

\section{STUDY AREA}

The floodable park "La Marjal" is located in San Juan urban area. This coastal municipality belongs to Alicante province (SE Spain). As a consequence of an unplanned and poorly managed urban growth during last decades, part of the San Juan municipality was edified in a natural floodplain or Marjal.

After studying different alternatives, Alicante local government selected the Marjal project to avoid problems derived from flash flood in this area. The Park was placed in a municipal smallholding of $36,700 \mathrm{~m}^{2}$ classified as green area. It is also part of a smallholdings set with the same classification which compound the Urban Park of San Juan Beach.

The peculiarity of the project consists in the occasional use of a public park as a temporal storage for high rainfalls (storms). The park was constructed since 2013 to 2015 with a total cost of $€ 3,307,855$ being the first built in Spain and the second in Europe (Fig. 3). Currently, the park is managed by the Aguas Municipalizadas de Alicante Company and the Alicante local government and presents a total capacity of 45,000 $\mathrm{m}^{3}$ (AMAEM [7]).

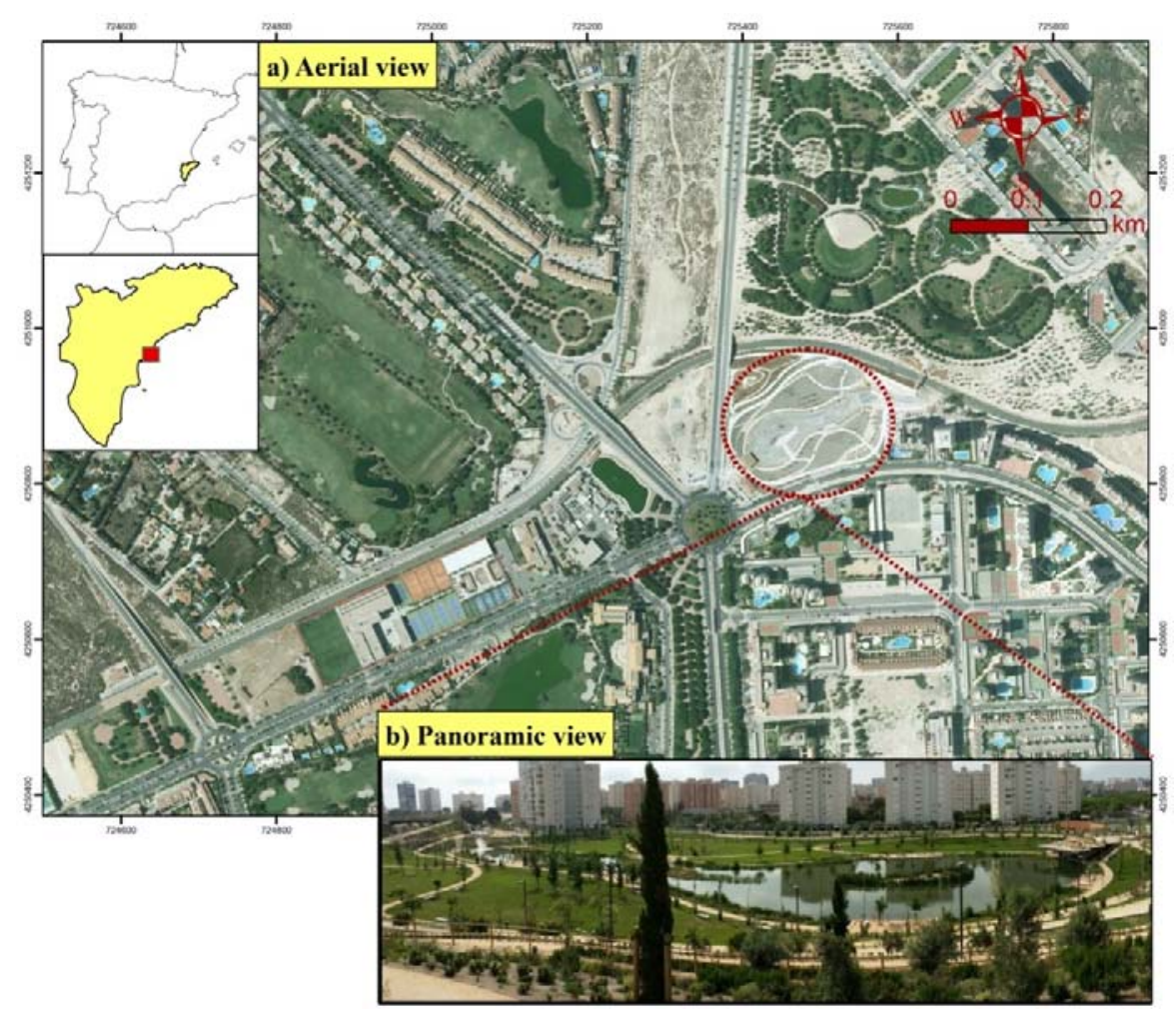

Figure 3: Location of the floodable park "La Marjal" into the Alicante province. (a) Aerial view; (b) Panoramic view. 


\section{ADVANTAGES AND USES}

\subsection{Barrier against flash flood}

The urban growth of Alicante city occupied a coastal area called San Juan Beach. Construction of an important network to retain rainfalls got to avoid effects of typical precipitations existing in the study area varies between $300 \mathrm{~mm} /$ year and $350 \mathrm{~mm} /$ year (Fig. 4). However, in case of heavy and concentrated rainfalls the mentioned network was insufficient and flash floods affected several avenues, the tram railway and private buildings in the lower part of San Juan urban area. This problem was solved with the floodable park "La Marjal" construction as a reservoir to retain rainfalls (storms) fallen in its natural watershed (Fig. 4). The park was designed to retain a total volume of $45,000 \mathrm{~m}^{3}$ according to a storm with a return period of 50 year (AMAEM [7]; Morote-Seguido et al. [8]).

The design of the floodable park "La Marjal" is based on the marshes dynamic. These are depressions or plains separated from the sea by a chain of dunes that, in precipitation times, accumulate flows from their natural watersheds generating specific habitats as for example the Pego-Oliva marsh, the Valencia coastal lagoon, and so one. Based on this idea a hydraulic system was designed. During a heavy rainfall episode, when the existing rainwater network capacity is exceeded, water surplus is derived through a lateral spillway to a collector with a diameter of $2000 \mathrm{~mm}$ which ends into the Park.

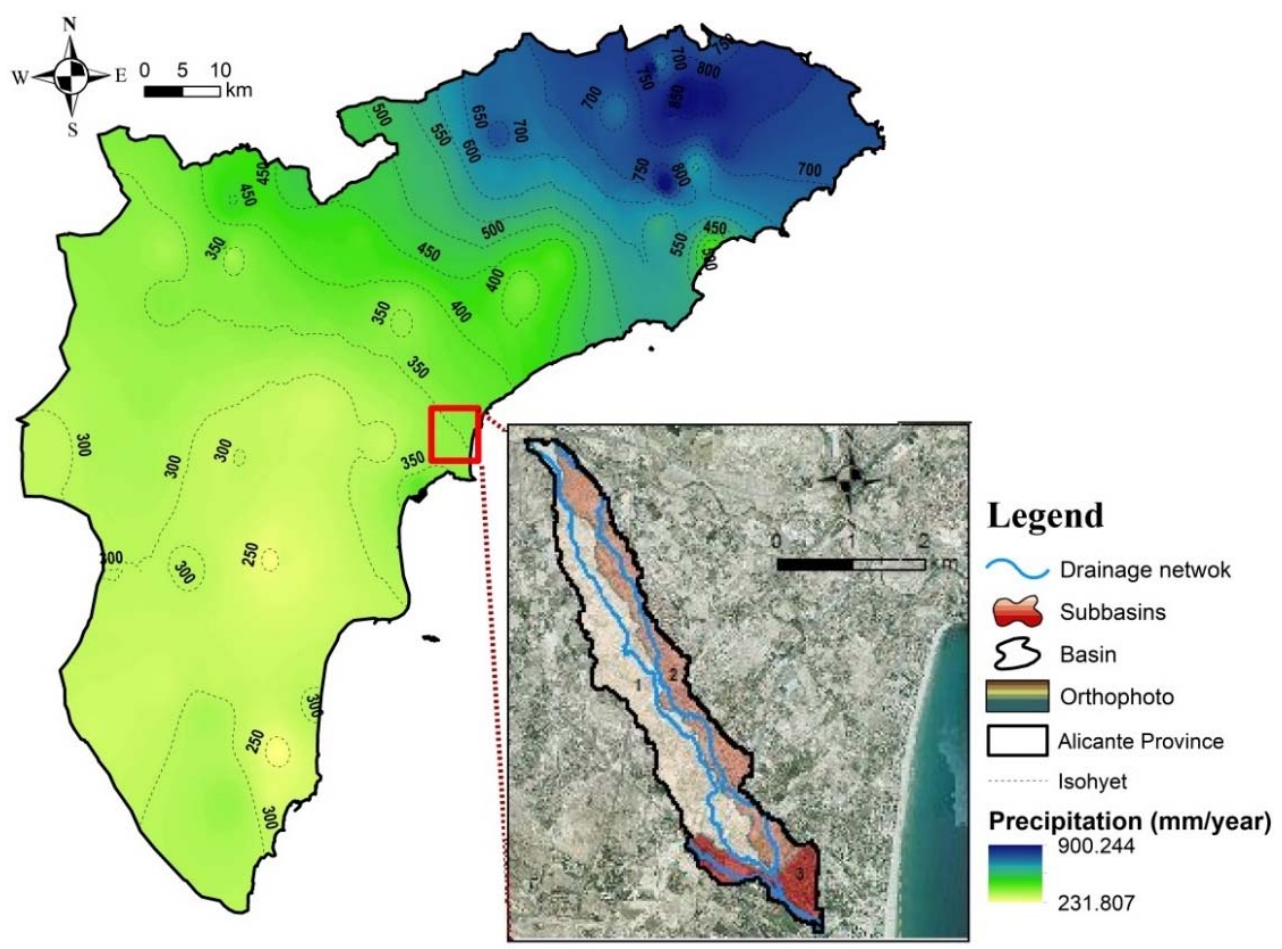

Figure 4: Average precipitation in Alicante province (left); Natural watershed of the floodable park "La Marjal" with an area of $6.38 \mathrm{~km}^{2}$ (right). This watershed was obtained with the SWAT hydrology model (Arnold et al. [9]; Winchell et al. [10]). 
Then, water is discharged on the surface of a pond located at the bottom of the park. This pond is a decorative element and only intervenes in the hydraulic function of the Park as a rainfall retention structure. When water overflows by its edges, the retention storage of the park slowly fills up. In case of exceeding its capacity $\left(45,000 \mathrm{~m}^{3}\right)$, the park has a spillway to evacuate water surplus directly to the sea by surface runoff. When the rainfall has finished and the network flow has reduced, the retained water in the Park is returned to the existing network. Then it is discharged into the sea, or sent to a wastewater pumping station placed in the same smallholding of the Park, for its later treatment in a municipal wastewater treatment plant (AMAEM [7]).

\subsection{Circular economy and water reuse}

The floodable park "La Marjal" provided numerous environment and economic benefits to San Juan urban area. Principal advantages are listed below:

- Water treatment and reuse of stored water.

Water stored in the park can be discharged into the sea or sent to a wastewater pumping station located in the same smallholding of the Park, for its later treatment in a municipal wastewater treatment plant. At the same time, irrigation of the floodable park "La Marjal" and ponds is performed with reclaimed water produced in municipal wastewater treatment plants. This is a perfect water cycle that has created a varied topography in this area. It has allowed growth of autochthonous vegetation and fauna helping the tourism of San Juan urban area.

- Recuperation of autochthonous vegetation and fauna.

The park presents a new green area with autochthonous and endemic vegetation from four natural habitats typical of the Alicante geography: riparian, mountain, dry agricultural terraces and diverse vegetation. Native fauna as ducks, coots, mosquitofishes (Gambusia affinis), etc. has colonised these habitats.

- Reduction of environmental impacts.

The floodable park "La Marjal" has reduced flash floods effects in San Juan area. Simultaneously, it has avoided direct polluted water discharges into the sea.

- Reduced economic cost.

Local Alicante government studied many alternatives to mitigate flash floods effects in the study area. Marjal project was chosen in part by its minimum costs. During project execution numerous operations were affected by a reduced budget. For example, excavated and moved land to form the mentioned park was placed next to this area creating a hill set. On these hills were made many agricultural plantations with typical crops of Alicante province. The total volume of land moved into hills was $20,000 \mathrm{~m}^{3}$. Thanks to this action costs derived from land transport were minimized.

- Increase of social gains and tourism.

The floodable park "La Marjal" presents numerous attractive elements to the public. Main tourism attraction is probably the great pond, a large permanent sheet of water of $6,674 \mathrm{~m}^{2}$ located in the middle of the park. This sheet of water recreates a primordial marsh. It contains two islands as a space for nesting birds giving to the park a high landscape attractive. The park also shows a waterfall, a perimeter path, many viewpoints, recreational areas, and so one (AMAEM [7]; Morote-Seguido and Hernández-Hernández [11]). 


\section{CONCLUSIONS}

Circular economy is a new economic trend associated principally with a sustainable development. The main objectives of this conception consist on preserve the value of products, materials and resources the maximum as possible into the economy. Simultaneously, it pretends to obtain a high reduction of the generated waste products into the economic cycle. Respect to water reuse into circular economy, in the water sector, circular economy is based on reusing water the most time as possible simulating a natural hydrological cycle. In the urban sector, using regenerated wastewater, circular economy pretends to mitigate net consumption of water, reusing it in different applications. In the industrial sector, the regenerated water coming from effluents can be reused to generate new products, use process and cooling water among other applications. It can be reduced environmental impacts derived from industrial activities and save costs. Therefore, circular economy of water is a valid mechanism to avoid problems derived from droughts and water scarcity.

Throughout the study, it has become evident that the floodable park "La Marjal" can be considered as a perfect instrument designed from the circular economy and sustainable development perspective. The park solves the problem for which it was designed: flash flood effects in San Juan urban area and provides diary storage of reclaimed water to reuse it in irrigate the park crops, send it into wastewater plants, and other uses. In particular, it was designed to retain a total volume of $45,000 \mathrm{~m}^{3}$ according to a storm with a return period of 50 year. At the same time, it allows reducing costs derived from water uses, reduce environmental impacts, recuperate autochthonous vegetation and fauna, etc. It is also a tourism attractive giving economic benefits to San Juan urban area.

The floodable park "La Marjal" construction received the award for the best integration in the space and respect for the environment of the Alicante province, granted by the Public Works Federation of the Alicante province (FOPA) in 2015 (AMAEM [7]).

\section{ACKNOWLEDGEMENTS}

Financial support was provided partially by the Fundación Séneca-Agencia de la Ciencia y la Tecnología, project 19325/PI/15. This study also has been conducted within the grant received from the Programa Nacional de Formación de Profesorado Universitario (FPU) conceded by the Spanish Ministry of Science to the first author. In the same way, the authors acknowledge detail information about the Marjal Project facilitated by members of Aguas Municipalizadas de Alicante, Empresa Mixta (AMAEM). The authors also acknowledge the reviewers of the manuscript whose comments contributed greatly to improve this paper.

\section{REFERENCES}

[1] McKinsey \& Company (eds), The Circular Economy: Moving From Theory to Practice, McKinsey Center for Business and Environment, pp. 1-40, 2016.

[2] Melgarejo, J. \& Prats-Rico, D., Desalación y reutilización de aguas. Situación en la provincia de Alicante, Confederación empresarial de la provincia de Alicante (COEPA): Alicante, pp. 1-172, 2006.

[3] MacArthur, E., Foundation Online. https://www.ellenmacarthurfoundation.org/. Accessed on: 23 Nov. 2017.

[4] Melgarejo, J. \& López-Ortiz, M.I., Depuración y reutilización de aguas en España (Wastewater treatment and water reuse in Spain). Agua y Territorio, 8, pp. 22-35, 2016.

[5] Camarasa-Belmonte, A.M., Flash floods in Mediterranean ephemeral streams in Valencia Region (Spain). Journal of Hydrology, 541, pp. 99-115, 2016. 
[6] Valdes-Abellan, J., Pardo, M.A. \& Tenza-Abril, A.J., Observed precipitation trend changes in the western Mediterranean region. International Journal of Climatology, 37(S1), pp. 1285-1296, 2017.

[7] AMAEM (ed), Parque de Inundación "La Marjal”. Un singular depósito de retención de aguas pluviales, Aguas Municipalizadas de Alicante, Empresa Mixta: Alicante, pp. 1-78, 2016.

[8] Morote-Seguido, A.F., Olcina-Cantos, J. \& Hernández-Hernández, M., La adaptación al cambio climático en la ciudad de Alicante. Medidas adoptadas desde la gestión de los recursos hídricos. Proceedings of Naturaleza, Territorio y Ciudad en un mundo global XXV Congreso de la Asociación de Geógrafos Españoles (AGE), pp. 729-738, 2017.

[9] Arnold, J.G., Srinivasan, R., Muttiah, R.S. \& Williams, J.R., Large area hydrologic modeling and assessment part I: model development. JAWRA Journal of the American Water Resources Association, 34(1), pp. 73-89, 1998.

[10] Winchell, M., Srinivasan, R.S., Di Luzio, M. \& Arnold, J.G., ArcSWAT Interface for SWAT2012. User's Guide, Texas Water Resources Institute: Texas, pp. 1-464, 2013.

[11] Morote-Seguido, A.F. \& Hernández-Hernández, M., El uso de aguas pluviales en la ciudad de Alicante. De Viejas ideas a nuevos enfoques. Papeles de Geografia, 63, pp. $1-19,2017$. 